\title{
Implementasi Isi atau Materi Pendidikan (Iman, Islam, Ihsan, Amal Saleh, Dan Islah) Di SD Muhammadiyah 7 Pekanbaru
}

\author{
M. Hatta \\ Sekolah Tinggi Agama Islam Sulthan Syarif Hasyim Siak, Indonesia \\ mhatta@gmail.com
}

\begin{abstract}
Abstrak
Salah satu elemen pendidikan yang tidak kalah pentingnya adalah materi pendidikan. Materi pendidikan bagian dari kurikulum yang harus disampaikan kepada peserta didik. Oleh sebab itu maka kajian mengenai materi pendidikan menjadi bagian khusus yang tidak terpisahkan dari kurikulum. materi pendidikan yang baik didasari oleh konsep dan landasan teori yang bisa dipertanggungjawabkan. Dalam kajian tulisan ini memuat materi pendidikan berdasarkan konsep pendidikan islam. Konsep pendidikan Islam menawarkan banyak keutamaan, antara lain karena bersumber dari kebenaran ilmiah, meliputi segenap aspek kehidupan manusia, berlaku universal, tidak terbatas hanya untuk bangsa tertentu saja, berlaku sepanjang masa, sangat sesuai dengan fitrah kemanusiaan bahkan menyiapkan pengembangan naluri-naluri kemanusiaan sehingga tercapai kebahagiaan yang hakiki. Oleh karena itu, tuntutan utama dalam pengembangan materi pendidikan Islam, bukanlah materi yang padat, lebih dari itu adalah kemampuan-kemampuan yang membawa siswa menguasai ketrampilan hidup (life skill) yang Islami. diantara materi pendidikan yang menjadi bahsanan adalah Isi atau Materi Pendidikan (Iman, Islam, Ihsan, Amal Saleh, Dan Islah).
\end{abstract}

Kata Kunci: Implementasi, Isi, Materi, Pendiidkan, (Iman, Islam, Ihsan, Amal Saleh, Dan Islah)

\section{PENDAHULUAN}

Tujuan pendidikan nasional adalah mengembangkan kemampuan dan membentuk watak serta peradaban bangsa yang bermartabat dalam rangka mencerdaskan kehidupan bangsa, bertujuan untuk berkembangnya potensi peserta didik agar menjadi manusia yang beriman dan bertakwa kepada Tuhan Yang Maha Esa, berakhlak mulia, sehat, berilmu, cakap, kreatif, mandiri, dan menjadi warga negara yang demokratis serta bertanggung jawab. ${ }^{.}$Pendidikan islam merupakan salah satu sistem dalam mengembangkan potensi peserta didik. Oleh sebab itu Pendidikan Islam harus dilakukan secara sadar untuk mencapai tujuan yang jelas melalui syariat Islam. Pendidikan Islam berlaku universal dan hendaknya diarahkan untuk menyadarkan manusia bahwa diri

${ }^{1}$ UU. Sisdiknas Nomor 20 Tahun 2003 
mereka adalah hamba Tuhan yang berfungsi menghambakan kepada-Nya. Jadi tujuan pendidikan Islam adalah menyadarkan manusia agar dapat mewujudkan penghambaan diri kepada Allah SWT. baik secara sendiri-sendiri maupun secara bersama-sama. Dengan demikian, konsep pendidikan Islam tidak boleh dan tidak dipisahkan dari konsepsi Ketuhanan.

Konsep pendidikan Islam menawarkan banyak keutamaan, antara lain karena bersumber dari kebenaran ilmiah, meliputi segenap aspek kehidupan manusia, berlaku universal, tidak terbatas hanya untuk bangsa tertentu saja, berlaku sepanjang masa, sangat sesuai dengan fitrah kemanusiaan bahkan menyiapkan pengembangan naluri-naluri kemanusiaan sehingga tercapai kebahagiaan yang hakiki. Selanjutnya pendidikan islam juga menawarkan materi-materi yang sesuai dengan perkembangan dan tuntutan dari masa kemasa sesuai dengan perkembangan ilmu pengetahuan. Sebelum dibicarakan lebih lanjut tentang materi pendidikan Islam, terlebih dahulu dibicarakan konsep pendidikan Islam, di dalamnya paling tidak ditemukan tiga unsur penting yang menunjukkan bahwa; pendidikan adalah alat untuk pemindahan nilai-nilai budaya; pendidikan mengandung makna proses latihan, dan pendidikan juga mengandung makna indoktrinasi nilainilai absolut yang terkandung dalam ajaran Islam. $^{2}$ Pertama, pendidikan berarti ditujukan untuk melaksanakan transformasi nilai-nilai kebudayaan Islam dari suatu generasi kepada generasi berikutnya ; kedua, pendidikan ditujukan untuk pengembangan potensipotensi individu ; ketiga, pendidikan berarti harus mampu menanamkan nilai-

2 Hasan Langgulung,. Pendidikan Islam Menghadapi Abad ke-21, Jakarta : Pustaka alHusna. 1996. Hlm. 4-9 nilai absolut yang tidak dapat berubah dalam berbagai ruang dan waktu. Untuk yang terakhir ini disebut sebagai bagian inti dari ajaran Islam.

Pemikiran tentang materi atau content pendidikan Islam secara umum dewasa ini lebih cenderung lahir dari persoalan kebutuhan yang seharusnya diberikan kepada siswa. Untuk mengidentifikasi kebutuhan ini, ahli-ahli pendidik menerjemahkan materi atau content dalam bentuk yang lebih konkret. Walker misalnya memberi penekanan makna materi pembelajaran yaitu apa yang seharusnya dapat diajarkan, dipelajari dan dibelajarkan kepada para siswa. Dalam hal ini berupa keperluan-keperluan hidup siswa. ${ }^{3}$ Pada sekelompok orang, materi pendidikan Islam sering diartikan dalam bentuk penjumlahan pengetahuan, ketrampilan atau nilai. Jika ingin menyesuaikan pendidikan Islam dengan kehidupan modern, maka yang perlu dilakukan adalah upaya untuk menggabungkan ilmu-ilmu Islam dan ilmu-ilmu Barat dalam kurikulum. Untuk sejumlah lembaga-lembaga pendidikan Islam bentuk penjumlahan ini telah banyak dilakukan, dan cara-cara ini bahkan telah dianggap sebagai salah satu cara yang paling tepat untuk meresponi tuntutan kehidupan modern dari sisi pendidikan Islam. Namun, yang amat perlu untuk digarisbawahi adalah bahwa materi pendidikan sebenarnya tidak hanya perlu dimaknai dalam arti penjumlahan ilmu pengetahuan, nilai dan ketrampilan sebagaimana telah dikemukakan di atas. pengembangan materi pendidikan Islam bukanlah sekedar untuk menggabungkan muatan materi pendidikan agama dan

\footnotetext{
3Walker. "What Curriculum Research?" dalam Curriculum And Instruction. Henry A. Giroux, et al. McCutchan USA : Publishing Corporation. 1981. Hlm. 283
} 
umum seperti yang disinggung atau banyak dilakukan banyak orang. Pemahaman seperti itu justru dapat membawa muatan kurikulum pendidikan Islam di samping sangat padat, tetapi juga mengakibatkan para siswa merasa susah untuk mengikuti materi tersebut.

Yang perlu disadari adalah bagaimana menciptakan formulasi rancangan materi pendidikan dan pembelajaran yang secara kualitatif mampu membangun nilai-nilai Islami. Semua bentuk pengetahuan, ketrampilan dan nilai yang dipelajari dapat diinternalisasi dari sisi keislaman. Oleh karena itu, tuntutan utama dalam pengembangan materi pendidikan Islam, bukanlah materi yang padat, lebih dari itu adalah kemampuan-kemampuan yang membawa siswa menguasai ketrampilan hidup (life skill) yang Islami. Ketrampilan-ketrampilan tersebut antara lain berhubungan dengan keterampilan berpikir, emosi, ketrampilan sosial, politik, ibadah, olah raga, kesehatan, kesenian, hukum, ekonomi, ilmu pengetahuan, dan sebagainya. Semua ketrampilan dikembangkan lewat proses rancangan pengembangan materi di mana bangunannya diletakkan di atas konsep-konsep spiritual Islam. Inilah makna pengembangan materi pendidikan yang dimaknai sebagai profil materi pendidikan Islam. Dari permasalahan diatas penulis ingin melihat "Implementasi Isi atau Materi Pendidikan (Iman, Islam, Ihsan, Amal Saleh, Dan Islah) di SD Muhammadiah 7 Pekanbaru."

Rumusan Masalah dalam tulisan ini dapat dirumuskan sebagaiberikut: 1) Bagaimana Efektivitas Pembelajaran Melalui impelementasi Isi atau Materi Pendidikan (Iman, Islam, Ihsan, Amal Saleh, Dan Islah) di SD Muhammadiyah 7 Pekanbaru 2) Faktor-faktor yang mempengaruhi Efektivitas Pembelajaran Melalui implementasi Isi atau Materi
Pendidikan (Iman, Islam, Ihsan, Amal Saleh, Dan Islah) di SD Muhammadiyah 7 Pekanbaru.

Tujun dalam tulisan ini adalah: 1) Mengatahui Efektivitas Pembelajaran Melalui implementasi Isi atau Materi Pendidikan (Iman, Islam, Ihsan, Amal Saleh, Dan Islah) di SD Muhammadiyah 7 Pekanbaru 2) Mengetahui Faktorfaktor yang mempengaruhi Efektivitas Pembelajaran Melalui implementasi Isi atau Materi Pendidikan (Iman, Islam, Ihsan, Amal Saleh, Dan Islah) di SD Muhammadiyah 7 Pekanbaru

\section{KAJIAN TEORI}

\section{A. Materi Pelajaran}

Isi atau materi pelajaran merupakan komponen kedua dalam sistem pembelajaran. Dalam konteks tertentu, materi pelajaran merupakan inti dalam proses pembelajaran. Artinya, sering terjadi dalam proses pembelajaran diartikan sebagai proses penyampaian materi. Hal ini bisa dibenarkan manakala tujuan utama pembelajaran adalah penguasaan materi pembelajaran (subject centered teaching). Dalam kondisi semacam ini, maka penguasaan materi pelajaran oleh guru mutlak diperlukan. Guru perlu memahami secara detail isi materi pelajaran yang harus dikuasai siswa, sebab peran dan tugas guru adalah sebagai sumber belajar. Materi pelajaran tersebut biasanya digambarkan dalam buku teks, sehingga sering terjadi proses pembelajaran adalah menyampaikan materi yang ada dalam buku. Namun demikian, dalam setting pembelajaran yang berorientasi pada pencapaian tujuan atau kompetensi, tugas dan tanggung jawab guru bukanlah sebagai sumber belajar. Dengan demikian, materi pelajaran sebenarnya bisa diambil 
dari berbagai sumber. ${ }^{4}$ Materi pembelajaran atau materi ajar (instructional materials) adalah pengetahuan, sikap dan keterampilan yang harus dipelajari siswa dalam rangka mencapai standar kompetensi yang telah ditentukan. ${ }^{48}$ Materi pelajaran diartikan pula sebagai bahan pelajaran yang harus dikuasai oleh siswa sesuai dengan tujuan pembelajaran.

Peran materi pembelajaran dalam proses pendidikan menempati posisi yang sangat strategis dan turut menentukan tercapainya tujuan pendidikan, karena materi pembelajaran merupakan input instrumental (instrumental input) bersama dengan kurikulum/program pendidikan, guru, media, evaluasi, dan sebagainya. Materi pembelajaran merupakan salah satu aspek yang dapat mempengaruhi output. Dengan kata lain kualitas proses dan hasil pendidikan, dapat dipengaruhi oleh materi pembelajaran yang digunakan. Atas dasar itulah, dalam sistem pendidikan, materi pembelajaran memegang peran yang cukup penting dan menentukan.

Tugas guru disini adalah bagaimana guru dapat menyampaikan atau menyajikan materi pelajaran dengan semenarik mungkin, sehingga siswa termotivasi untuk mengikuti proses belajar mengajar dengan baik dan penuh semangat. Usaha yang dapat dilakukan oleh guru adalah mengkombinasi dan mengkoordinasikan materi pelajaran dengan media dan strategi pembelajaran yang relevan. Hal ini tentu saja harus didukung dengan penguasaan materi atau bahan pelajaran yang ia sajikan dengan penggunaan bahasa yang baik dan benar. ${ }^{5}$

Diantara materi yang bersumber dari agama antara lain seperti: 1) islam, 2)

${ }^{4}$ Wina, Strategi Pembelajaran Berorientasi Standar Proses Pendidikan, hlm. 60.

5 Syaiful Sagala, Konsep dan Makna Pembelajaran, hlm. 162. iman, 3) ihsan, 4) amal saleh dan 5) islah. Berikut penjelasan dari lima aspek isi atau materi pendidikan tersebut.

\section{Iman}

Iman berasal dari Bahasa Arab dari kata dasar amana yu'minuimanan. Artinya beriman atau percaya. Percaya dalam Bahasa Indonesia artinya meyakini atau yakin bahwa sesuatu (yang dipercaya) itu memang benar atau nyata adanya. ${ }^{6}$ Iman dapat dimaknai iktiraf, membenarkan, mengakui, pembenaran yang bersifat khusus. $^{7}$ Menurut WJS. Poerwadarminta iman adalah kepercayaan, keyakinan, ketetapan hati atau keteguhan hati. ${ }^{8}$ Abul 'Ala al-Mahmudi menterjemahkan iman dalam Bahasa inggris Faith, yaitu to know, to believe, to be convinced beyond the last shadow of doubt yang artinya, mengetahui, mempercayai, meyakini yang didalamnya tidak terdapat keraguan apapun. ${ }^{9}$ HAR Gibb dan JH Krammers memberikan pengertian iman ialah percaya kepada Allah, percaa kepada utusan-Nya, dan percaya kepada amanat atau apa yang dibawa/berita yang dibawa oleh utusannya. ${ }^{10}$

Bila kita perhatikan penggunaan kata Iman dalam Al- Qur'an, akan mendapatinya dalam dua pengertian

${ }^{6}$ Kaelany HD, Iman, Ilmu dan Amal Saleh, Jakarta: Rineka Cipta, 2000, hlm. 58.

7 Dr.Abdul Rahman Abdul Khalid, Garis Pemisah antara Kufur dan Iman, Jakarta, Bumi Aksara,1996. Hlm. 2

8 WJS. Poerwadarminta, Kamus Umum Bahasa Indonesia, Jakarta: Balai Pustaka, 2000, hlm. 18.

${ }^{9}$ Abu A'la Al-Maududi, Toward Understanding, Comiti Riyadh: Islamic Dakwah, 1985, hlm. 18.

${ }^{10}$ HAR. Gibb and JH Krammers, Shorter Encyclopaedia of islam, E.J. Brill, Leiden, 1974, hlm 167 
dasar, ${ }^{11}$ yaitu: 1) Iman dengan pengertian membenarkan adalah membenarkan berita yang datangnya dari Allah dan Rasul-Nya. Dalam salah satu hadist shahih diceritakan bahwa Rasulullah ketika menjawab pertanyaan Jibril tentang Iman yang artinya bahwa yang dikatakan Iman itu adalah engkau beriman kepada Allah, malaikat-Nya, kitab-kitab-Nya, Rasul-rasul-Nya, hari kiamat dan engkau beriman bahwa Qadar baik dan buruk adalah dari Allah SWT. 2) Iman dengan pengertian amal atau ber-iltizam dengan amal : segala perbuatan kebajikan yang tidak bertentangan dengan hukum yang telah digariskan oleh syara'. Dalam sebuah ayat dalam al-quran surat al-hujarot: ayat 15:

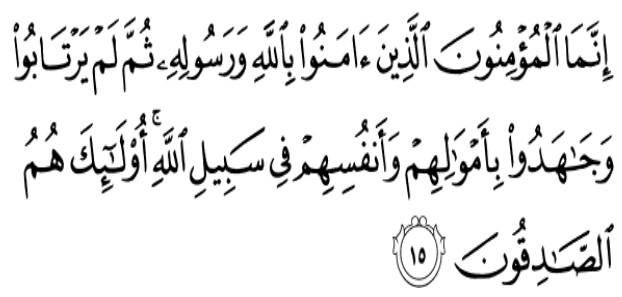

Artinya: Sesungguhnya orang-orang yang beriman itu hanyalah orang-orang yang percaya (beriman) kepada Allah dan Rasul-Nya, kemudian mereka tidak ragu-ragu dan mereka berjuang (berjihad) dengan harta dan jiwa mereka pada jalan Allah. mereka Itulah orang-orang yang benar.

Dari ayat tersebut, dapat dikatakan bahwa Iman adalah membenarkan Allah dan RasulNya tanpa keraguan, berjihad di jalan Allah dengan harta dan jiwa. Pada akhir ayat tersebut "mereka Itulah orang-orang yang benar" merupakan indikasi bahwa pada waktu itu ada golongan yang mengaku beriman tanpa bukti, golongan ini sungguh telah berdusta dan

\footnotetext{
11 Op.Cit. Garis Pemisah antara Kufur dan Iman. Hlm 1
}

mereka tidak dapat memahami hakikat iman dengan sebenarnya. Mereka menganggap bahwa iman itu hanya pengucapan yang dilakukan oleh bibir, tanpa pembuktian apapun. Inti pendidikan agama terletak pada pendidikan keimanan. Para psikolog berpendapat bahwa dalam keimanan kepada allah Swt. Terdapat kekuatan spiritual luar biasa yang dapat membantu orang beriman mengatasi kegelisahan, ketegangan, dan kesulitan hidup di zaman modern ini. ${ }^{12}$ Dunia modern yang telah dikuasai oleh kehidupan material dan di dominasi oleh persaingan keras untuk mendapatkan materi, telah menimbulkan ketegangan, stress, dan kegelisahan, atau bahkan penyakit kejiwaan lainnya dalam diri manusian yang miskin akan nilai spiritual.

Seorang psikoanalisis, A.A. Brill berkata bahwa "orang yang beragama secara benar sama sekali tidak akan menderita penyakit kejiwaan". Berdasarkan eksperimennya, orang beragama yang terbiasa mendatangi tempat-tempat ibadah mempunyai kepribadian yang lebih baik daripada mereka yang tidak beragama atau yang tidak menjalankan ibadah apapun. ${ }^{13} \mathrm{Al}-$ Qur'an menjelaskan perasaan aman dan tentram karena adanya iman di hati dalam surat Ar Ra'd ayat 28:

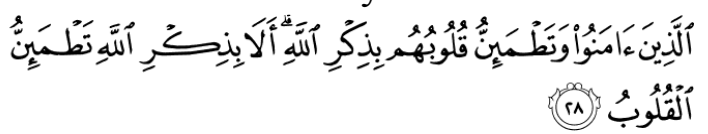

Artinya "Yaitu orang-orang yang beriman dan hati mereka menjadi tentram dengan mengingat Allah. Ingatlah, hanya dengan mengingat Allah

Dari ayat tersebut jelas bahwa ingat kepada Allah merupakan salah satu

12 Muhammad Usman Najati, AlQur'an dan Psikologi, (terj. Ade Asnawi dari Al Qur'an wa ilm 1 Nafs, Aras Pustaka, Jakarta, hlm. 217

13 Ibid, hal. 217 
cara merefleksikan keimanan kepadaNya. Iman kepada Allah juga dapat diwujudkan dengan jalan mengikuti semua tuntunan yang telah digariskanNya. Hal itulah satu-satu nya cara untuk mewujudkan rasa aman bagi manusia dan membebaskannya dari kegelisahan hidup.. Pendidikan iman yang dilakukan hendaknya didasarkan kepada wasiat dan petunjuk Rasulullah dalam menyampaikan dasar-dasar keimanan kepada anak. Sebab dalam diri Rasulullah terdapat teladan yang baik bagi setiap orang sebagaimana disebutkan dalam surat $\mathrm{Al}$ Ahzab ayat 21

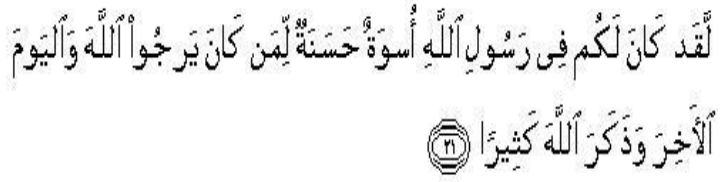

Artinya: "Sesungguhnya telah ada pada diri Raasulullah itu suri te ladan yang baik bagimu (yaitu) bagi orang yang mengharap rahmat Allah dan kedatangan hari kiamat dan dia banyak

Untuk mencapai hasil pendidikan keimanan yang diharapkan, sudah pasti tak dapat dilakukan tanpa mengikuti jejak dan teladan Rasulukllah saw. secara tepat dan benar Salah satunya adalah dengan merujuk kepada contoh dan teladan beliau yang dipaparkan dalam hadist-hadist yang shahih. Dalam salah satu hadist, beliau memaparkan bahwa akidah Islam itu mempunyai enam aspek (unsure, rukun), yakni iman kepada Allah, para malaikat-Nya, kitabkitab-Nya, para Rasul-Nya, iman kepada hari akhir dan juga kepada segala ketentuan yang digariskan-Nya. Sejarah telah membuktikan bahwa pendidikan keimanan kepada anak yang benar-benar berhasil mewarnai tata kehidupan masyarakat muslim hayalah yang ditunjukkan para sahabat Rasulullah saw. sebagai hasil perjuangan beliau.
Rasulullah tidak hanya memberikan teori yang tidak dibuktikan dalam kehidupan konkritnya, tetapi justru memberikan contoh da tuntunan praktis yang diperlukan dalam mendidik anak berdasarkan tauhid. Para sahabat meriwayatkan hadist tentang praktek beliau tersebut, banyak diantaranya yang masih berusia anak-anak. Mereka inilah yang mengalami secara langsung didikan Rasulullah dalam bidang keimanan. ${ }^{14}$

Menurut Muhammad Nur Abdul Hafizh, setidaknya terdapat lima pola dasar pembinaan akidah atau keimanan yang sesuai dengan petunjuk Rasulullah, yakni : a) Membacakan kalimat tauhid kepada anak b) Menanamkan kecintaan anak kepada Allah Swt. c) Menanamkan kecintaan anak kepada Rasulullah d) Mengajarkan Al-Qur'an kepada anak e) Menanamkan nilai perjuangan dan pengorbanan dalam diri anak. ${ }^{15}$

\section{Islam}

Kata Islam berasal dari bahasa Arab "S-L-M" ( Sin, Lam, Mim). Artinya antara lain: Damai, Suci, Patuh dan Taat (tidak pernah membantah). Dalam pengertian agama, kata Islam berarti kepatuhan kepada kehendak dan kemauan Allah, serta taat kepada hukum-Nya. Hubungan antara pengertian menurut kata dasar dan pengertian menurut agama erat dan nyata sekali, yaitu: "Hanya dengan k epatuhan kepada kehendak Allah dan tunduk kepada hukum-hukum-Nya seorang dapat mencapai kedamaian yang sesungguhnya dan memperoleh kesucian

${ }^{14}$ Muhammad Thalib, Praktek Rasulullah saw. Mendidik Anak (bidang aqidah dan Ibadah) Irsyad Baitus Salam, Bandung, 2000, hlm.12

15 Muhammad Nur Abdul Hafizh Suwaid, Mendidik Anak Bersama Rasulullah (terj. Kuswandani dari Manhaj al Tarbiyah al Nabawiyah li al Thifl), Al Bayan, Bandung, 2000, hlm. 110 
yang abadi". ${ }^{16}$ Islam, menurut Zuhairini, adalah menempuh jalan keselamatan dengan yakin menyerahkan diri sepenuhnya kepada Tuhan dan melaksanakan dengan penuh kepatuhan dan ketaatan akan segala ketentuanketentuan dan aturan-aturan oleh-Nya untuk mencapai kesejahteraan dan kesentosaan hidup dengan penuh keimanan dan kedamaian. ${ }^{17}$

Agama Islam mempunyai pengertian yang lebih luas dari pengertian agama pada umumnya. Di sini, kata Islam berasal dari Bahasa Arab yang mempunyai bermacam-macam arti, diantaranya sebagai berikut: ${ }^{18}$ 1) Salam yang artinya selamat, aman sentosa dan sejahtera, yaitu aturan hidup yang dapat menyelamatkan manusia di dunia dan akhirat. Kata salam terdapat dalam alQur"an Surah al-An"am ayat 54; Surah al-A"raf ayat 46; dan surah an-Nahl ayat 32. 2) Aslama yang artinya menyerah atau masuk Islam, yaitu agama yang mengajarkan penyerahan diri kepada Allah, tunduk dan taat kepada hukum Allah tanpa tawar- menawar. Kata aslama terdapat dalam al-Qur"an surah al-Baqarah ayat 112; surah al-Imran ayat 20 dan 83; surah an-Nisa ayat125; dan surah al-An"am ayat 14. 3) Silmun yang artinya keselamatan atau perdamaian, yakni agama yang mengajarkan hidup yang damai dan selamat. 4) Sulamun yang artinya tangga, kendaraan, yakni peraturan yang dapat mengangkat derajat kemanusiaan yang dapat mengantarkan orang kepada kehidupan yang bahagia.

Adapun kata Islam menurut istilah (terminologi) adalah mengacu kepada agama yang bersumber pada wahyu yang datang dari Allah SWT, bukan berasal

16 Hammudah Abdalati, Islam Suatu Kepastian, Media Da'wah, 1983, hlm. 13

17 Zuhairini, Filsafat Pendidikan Islam,

Jakarta: Rajawali Press, 1995, hlm. 36

${ }^{18}$ M. Yatimin Abdullah, Studi Islam

Kontemporer, (Jakarta: Amza, 2006), hlm. 5 dari manusia. Sebagai agama sempurna, Islam datang untuk menyempurnakan ajaran yang dibawa oleh Nabi-nabi Allah sebelum Nabi Muhammad. Kesempurnaan ajaran ini menjadi misi profetik (nubuwwah) kehadiran Nabi Muhammad SAW. Dalam al-Qur"an (Surah al-Ma"idah [5]: 3) ditemukan penegasan tentang kesempurnaan ajaran Islam.

Artinya:"Pada hari ini telah Kusempurnakan untuk kamu agamamu, dan telah Ku-cukupkan kepadamu nikmat-Ku, dan telah Ku-ridhai Islam itu Jadi agama bagimu."

Berdasarkan firman Allah di atas, jelas bahwa Islam adalah agama yang sempurna, agama yang memiliki ajaran yang mencakup semua aspek kehidupan, dan agama yang menggariskan metode kehidupan secara utuh.

\section{Ihsan}

Term ihsan berasal dari huruf alif, ha, sin dan nun . Di dalam alQur"an, kata ihsan bersama dengan berbagai derivasi dan kata jadiannya disebutkan secara berulang -ulang. Penyebutan tersebut terdapat sebanyak 108 kali yang disebut tersebar dalam 101 ayat dan pada 36 surat. ${ }^{19}$ Derivasi ihsan berupa fi'il mâdhi, ahsana disebut dalam al-Qur"an sebanyak 9 (sembilan) kali pada 9 (sembilan) ayat dan 8 (delapan) surat. Sedangkan kata ahsantum diulang sebanyak 2 (dua) kali pada 1 (satu) ayat dan 1 (satu) surat. Sementara ahsan $\hat{u}$ tercantum 6 (enam) kali pada 6 (enam) ayat dan 6 (enam) surat2. Perbedaan ungkapan tersebut terletak pada fấil-nya (subjek) yang secara umum terdiri dari Allah dan manusia, baik berupa isim zhâhir maupun isim dhamîr.

\footnotetext{
${ }^{19}$ Muhammad Fuad Abd al-Bâqî, Mu'jam al-Mufahras li Alfâzh al-Qur'an, (Darul Fikr, 1981), hlm. 202-205
} 
Lebih lengkapnya, berikut ini adalah daftar jumlah kata ihsan dengan berbagai derivasinya dalam al-Qur"an Lafadz dari huruf alif, ha, sin dan nun ini, selain menghasilkan term ihsan beserta derivasinya, juga dihasilkan pula term hasuna beserta derivasinya. Meski memiliki makna umum yang serupa, tapi kedua makna ini tidak berkonotasi ihsan.

Ayat ihsan yang bersinggungan dengan bakti terhadap orangtua memang mendominasi. Berdasarkan maknanya, kelima ayat tersebut dapat dikelompokkan dalam dua kelompok. Kelompok pertama adalah ayat -ayat yang mengandung perintah untuk berbuat baik kepada kedua orangtua (ibu-bapak) dan juga kepada orang lain, seperti kerabat, anak yatim, orang-orang miskin, tetangga dekat, tetangga jauh, teman sejawat, ibn sabil dan hamba sahaya, dan disertai pula dengan perintah beribadah semata-mata hanya kepada Allah dan tidak menyekutukan-Nya dengan sesuatu apa pun. Perintah ini secara eksplisit tertuang dalam surat alBaqarah [2] : 83.

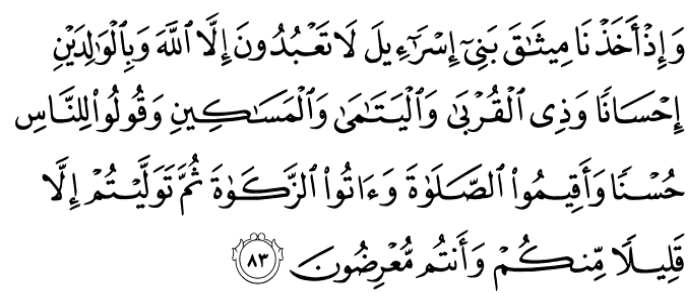

Artinya: "Dan (ingatlah) ketika Kami mengambil janji dari Bani Israil (yaitu): Janganlah kamu menyembah selain Allah, dan berbuat baiklah kepada ibu bapak, kaum kerabat, anak-anak yatim, dan orang-orang miskin, serta ucapkanlah kata-kata yang baik kepada manusia." (Q.S. al-Baqarah [2] : 83)

Ayat yang disebutkan di atas menunjukkan perbuatan ihsan yang mengarah pada bentuk perbuatan baik yang dilakukan oleh manusia. Perbuatan baik ini secara terkhusus dilakukan sebagai bentuk ibadah menyembah Allah sekaligus dengan diiringi bentuk perbuatan baik yang dilakukan manusia kepada sesamanya. Bila dimaknai lebih lanjut, ibadah manusia yang dilakukan dengan menyembah Allah dan tidak mempersekutukan Allah ini disertai dengan kewajiban -kewajiban lain yang berhubungan dengan perbuatan baik kepada sesama manusia. Di mana keutamaan perbuatan baik ini dilakukan terhadap kedua orangtua.

\section{Islah}

Menurut Abi al-Husain Ahmad ibn Fãris ibn Zakaria, kata islah berasal dari kata حلص. Lebih lanjut ia mengatakan bahwa Shalãh menunjuk pada arti yang berlawanan dengan kerusakan (al-fasãd). Ini berarti telah memperbaiki dengan perbaikan. Dikatakan shalaha (yang di-fathah lamnya) sesuai dengan yang dihikayatkan oleh Ibnu al-Sukiyat bahwa shalaha adalah shalaha-shulühan bermakna memperbaiki, sesuatu perbaikan". ${ }^{20}$

Secara istilah, term ishlãh dapat diartikan sebagai perbuatan terpuji dalam kaitannya dengan perilaku manusia. $^{21}$ Karena itu, dalam terminologi Islam secara umum, ishlãh dapat diartikan sebagai suatu aktifitas yang ingin membawa perubahan dari keadaan yang buruk menjadi keadaan yang baik. Dengan kata lain, perbuatan baik lawan dari perbuatan jelek. 'Abd Salam menyatakan bahwa makna shalaha yaitu memperbaiki semua amal

20 Abi al-Husain Ahmad ibn Fãris ibn Zakaria, Mu'jam Maqãyis al-Lughah, (Mesir: Maktabah al-Khabakhiy, 1981), Jilid. 3, hlm. 303

21 E. van Donzel, B. Lewis, dkk (ed), Encyclopedia of Islam, (Leiden: E.J. Brill, 1990), Jil. IV, hlm. 141 
perbuatannya dan segala urusannya. ${ }^{22}$ Dalam perspektif tafsir, al-Thabarsi dan al-Zamakhsyari dalam tafsirnya berpendapat, bahwa kata ishlãh mempunyai arti mengkondisikan sesuatu pada keadaan yang lurus dan mengembalikan fungsinya untuk dimanfaatkan. ${ }^{23}$

Kata ishlãh juga memiliki beberapa sinonim, di antaranya adalah tajdĩ (pembaruan) dan taghyir (perubahan), yang keduanya mengarah pada kemajuan dan perbaikan keadaan. ${ }^{24}$ Dengan demikian, ishlãh bertalian erat dengan tugas para Rasul yang terus ditindaklanjuti hingga sekarang dan seterusnya. Walaupun zaman para Nabi telah berakhir, namun pekerjaan ishlãh yakni perubahan ke arah perbaikan berlanjut terus sampai sekarang. Hal ini menunjukkan bahwa pekerjaan ishlãh merupakan bagian dari tanggung jawab manusia sebagai khalifah di muka bumi. Jhon O.Voll mengemukakan bahwa dua dari pengertian-pengertian utama dalam kosa kata Islam tentang kebangkitan adalah kata ishlãh dan tajdĩd. Ishlãh biasa diterjemahkan sebagai perubahan dan pembaruan. Secara bersama-sama, kedua kata tersebut mencerminkan satu tradisi berkelanjutan, yaitu tentang upaya menghidupkan kembali keimanan Islam

${ }^{22}$ Abd Salam, Mu'jam al-Wasith, (Teheran: Maktabat al-Ilmiyah, t.th), Jil. I, hlm. 522

${ }^{23} \mathrm{Abu}$ 'Ali al-Fadl ibn al-Hasan atThabarsi, Majma' al-Bayãn fi tafsĩr al-qur'an, (Beirut: Dar al-Ma'rifah, 1986), cet I, Jil. I, II, hlm. 137

24 John O. Voll, Renewal and Reform in Islamic History: Tajdid and Ishlãh dalam John L. Esposito, Voices of Resurgent, (New York: Oxford University Press, 1983), hlm. 32-42 beserta praktek-prakteknya dalam sejarah kamunitas kaum muslimin. ${ }^{25}$

Menurut Syafi'i Ma'arif, perkataan tajdĩd berarti pembaruan, inovasi, restorasi, medernisasi, penciptaan sesuatu yang baru, dan lainlain yang berkaitan dengan makna itu. Maka bila dihubungkan dengan pemikiran tajdĩd dalam Islam, tajdĩd adalah usaha dan upaya intelektual Islami untuk menyegarkan dan memperbaharui pengertian dan penghayatan umat Islam terhadap agamanya berhadapan dengan perubahan dan perkembangan masyarakat. Menurutnya, kerja adalah kerja ijtihad yang sangat strategis dalam membumikan ajaran-ajaran Islam dalam konteks ruang dan waktu. ${ }^{26}$

Dari keterangan di atas dapat diterangkan lebih lanjut bahwa, meskipun kata ishlãh dan kata shulh merupakan sinonim, namun kata ishlãh lebih menekankan arti suatu proses perdamaian antara dua pihak. Sedangkan kata shulh lebih menekankan arti hasil dari proses ishlãh tersebut yaitu berupa shulh (perdamaian/kedamaian). Dapat juga dinyatakan bahwa ishlãh mengisyaratkan diperlukannya pihak ketiga sebagai perantara atau mediator dalam penyelesaian konflik tersebut. Sementara dalam shulh tidak mengisyaratkan diperlukannya mediator.

Hasbi al-Shiddieqy menerangkan lebih lanjut bahwa pengertian ishlãh atau memperbaiki hubungan manusia yang bersengketa ialah mengeluarkan tali yang kuat dan kokoh di antara sesama manusia yang di dalamnya telah tumbuh persengketaan, baik mengenai urusan

25 John O. Voll, Renewal and Reform in Islamic History: Tajdid and Ishlãh dalam John L. Esposito, Voices of Resurgent, hlm. 22. ${ }^{26}$ Ahmad Syafi'i Ma'arif, Al-qur'an Realitas Sosial dan Limbo Sejarah (Sebuah refleksi), (Bandung: Penerbit Pustaka, 1985), cet. I, hlm. 95 
darah, urusan harta dan kehormatan, maupun mengenai urusan politik dan taktik perjuangan". ${ }^{27}$

Dari berbagai ayat yang menjelaskan tentang ishlãh, akan penulis deskripsikan beberapa ayat yang berkaitan dengan pembahasan dalam ini. Ayat-ayat tersebut antara lain adalah:

1). QS. al-Nisa' (4): 114

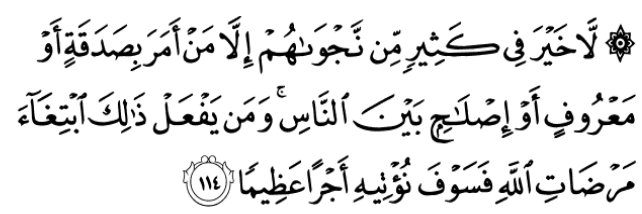

Artinya:

kebanyakan bisikan-bisikan mereka, kecuali bisikan-bisikan dari orang yang menyuruh (manusia) memberi sedekah, atau berbuat ma'ruf, atau mengadakan perdamaian di antara manusia. Dan barangsiapa yang berbuat demikian karena mencari keridhaan Allah, maka kelak Kami memberi kepadanya pahala ya

Ketika menafsirkan ayat ini, Rasyid Ridla menjelaskan bahwa ayat ini diturunkan berkenaan dengan kasus Thu'mah ibn Ubairiq yang dititipi baju besi oleh seorang Yahudi. Ketika tiba waktunya baju tersebut diambil oleh pemiliknya, Thu'mah berkonspirasi untuk mengingkari orang Yahudi tersebut bahkan meremehkannya. Karena terjadi keributan, maka akhirnya peristiwa ini sampai kepada Nabi. Hampir-hampir saja Nabi membela Thu'mah. Kemudian turunlah ayat ini, menjelaskan kepada Nabi perihal yang sebenarnya terjadi dan penyelesaiannya. $^{28}$

27 Hasbi al-Siddieqy, al-Islam II, (Jakarta: PT. Mutiara Bulan Bintang, 1952), cet. I, hlm. 448

${ }^{28}$ Rasyid Ridla, Tafsir al- Manãr, (Kairo: al- Hayat al-Mishriyahal- 'Ammah al- Kitab, 1975), juz ke-2, hlm. 406-407
2). QS. al-An'am (6): 54

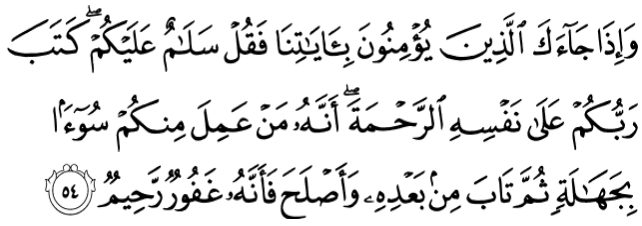

Artinya: "Apabila orang-orang yang beriman kepada ayat-ayat Kami itu datang kepadamu, Maka Katakanlah: "Salaamun alaikum". Tuhanmu telah menetapkan atas diri-Nya kasih sayang, (yaitu) bahwasanya barang siapa yang berbuat kejahatan di antara kamu lantaran kejahilan, Kemudian ia bertaubat setelah mengerjakannya dan mengadakan perbaikan, Maka Sesungguhnya Allah Maha Pengampun

Sebab turunnya surat al- $A n^{\prime} a m$ ayat 54 di atas ada kaitannya dengan ayat-ayat sebelumnya (QS. 6: 51, 52, 53) yang menerangkan tentang larangan kepada kaum mukminin untuk mengadakan penilaian martabat terhadap sesama manusia. Dalam satu riwayat dikemukakan bahwa pembesar Quraisy lewat di hadapan Rasulullah saw. yang sedang duduk bersama Khabab ibn alArat, Suhaib, Bilal, dan Ammãr (mereka adalah para hamba sahaya yang sudah dimerdekakan). Mereka berkata:

Muhammad, apakah engkau rela duduk setingkat dengan mereka, adakah mereka itu telah diberi nikmat oleh Allah lebih dari pada kami. Sekiranya engkau usir mereka, kami akan menjadi pengikutmu". Maka Allah menurunkan ayat 51,52, dan 53 tersebut yang memerintahkan kepada Nabi Muhammad untuk menyampaikan wahyu yang melarang kaum mukminin untu menilai derajat seseorang, karena sesungguhnya Allah lebih mengetahui orang-orang yang bersyukur kepadaNya. Setelah itu para pembesar Quraish tersebut meminta maaf karena ucapan mereka itu. Kemudian turunlah ayat 
selanjutnya, yaitu QS. al-An'am(6): 54 sebagai jaminan ampunan kepada orangorang yang taubat akibat berbuat kesalahan karena ketidaktahuannya. ${ }^{29}$

\section{Amal Shaleh}

Amal saleh terdiri dari dua kata yang masing-masing memiliki pengertian sendiri. Amal adalah semua perbuatan yang dikerjakan dan dengan niat tertentu. Dalam al-Quran kata amal jika dilihat dari maknanya sebagai perbuatan, maka berdekatan dengan beberapa kata atau ungkapan lain. Seperti fi'il, sa'yu, shan'u, kasab, dan jarah. Letak persamaan antara semua ungkapan tersebut adalah kesemuanya meliputi perbuatan manusia. Namun walaupun secara makna mereka berdekatan tetapi masing-masing memiliki fokus makna yang berbeda. Semisal antara kata amal dan . Amal memiliki makna yang lebih khusus dari kata fi'il. Term amal hanya khusus merujuk pada perbuatan-perbuatan yang dilakukan manusia dan hewan, sedangkan term fi'il juga digunakan untuk menunjuk perbuatan benda-benda mati. ${ }^{30}$ Begitupun dengan ungkapanungkapan lainnya, memiliki perbedaan makna dengan term amal.

Term amal kemudian berderivasi menjadi kata mu'amalah. Sebuah term dengan wazan yang menunjukan makna hubungan/aturan tingkah laku antara satu manusia dengan manusia lainnya. Istilah mu'amalah ini sangat popular dalam kajian hukum islam, saat membedakan antara prilaku manusia yang

${ }^{29}$ Qamaruddin Saleh, H.A.A Dahlan dkk. Asbab al-Nuzul(Latar Belakang Historis Turunnya Ayat-ayat Al-Qur'an), (Bandung: Penerbit CV. Diponegoro, 1985), cet. V, hlm. 205-206

30 Al-Raghib al-Asfahani, $M u^{\prime} j a m$ Mufradat alfaz al-Quran (Beirut: Dar al-Kutub al-Ilmiyah, 2004), hlm. 360 hubungannya dengan Tuhan dan yang hubungannya dengan sesama manusia (Hubungan dengan Allah disebut dengan ibadah dan hubungan dengan manusia disebut dengan $\quad{ }^{31}$ Derivasi dari kata amal kepada term mu'amalah ini yang memberikan pengertian tambahan kepada term amal bahwa di dalamnya terdapat keniscayaan perbuatan yang mempertemukan manusia dengan manusia yang lain. Dari sini maka amal-muamalah akhirnya terkadang disejajarkan pula dengan istilah akhlaq dan etika. ${ }^{32}$ Sebab semuanya dianggap berkaitan dengan pembicaraan tentang aturan laku yang terdapat dalam hubungan antara sesama manusia.

Adapun Metode pelaksanaan amal shaleh yang bisa diterapkan dilembaga pendidikan islam adalah dengan metode berikut; 1) Ceramah dan Tanya Jawab 2) Demonstras 3) Pemberian tugas. 4) Muhasabah 5) Eksperimen 6) Talqin 7) Musyawaroh. 8) Mujahadah.

\section{PEMBAHASAN}

Sekolah Dasar Muhammadiyah 7 Pekanbaru merupakan sekolah dasar terpadu yang mengintegrasikan pendidikan umum dan agama. selanjutnya sekolah ini memiliki visi, misi dan tujuan sebagai berikut: pertama, visi "Terwujudnya Lembaga Pendidikan Islami yang Berprestasi, berbudaya ilmu pengetahuan, teknologi, seni budaya dan lingkungan, serta mampu berdaya saing secara global." kedua, misi : (1) Meningkatkan pemahaman dan pengamalan ajaran Islam disertai akhlakul karimah. (2)

${ }^{31}$ Mahsun Fuad, Hukum Islam Indonesia; Dari Nalar Partisipatoris Hingga Emansipatoris (Yogyakarta: LKis, 2005

32 Qurais Syihab, “Iman dan Amal Saleh", Amanah, no 87, November 1988, hlm 177 
Membentuk Kepribadian yang tangguh berlandaskan IMTAQ dan IPTEK. (3) Meningkatkan semangat keunggulan global dan bernalar sehat kepada para siswa, guru dan karyawan sehingga berkemauan kuat untuk maju. (4) Melayani Pendidikan dengan memperhatikan perbedaan kecerdasan, kecakapan, bakat dan minat peserta didik. (5) Menumbuhkembangkan eksistensi peserta didik melalui proses pendidikan yang bermartabat, kreatif, inovatif dan eksperimentatif. (6) Meningkatkan kesadaran memelihara lingkungan sehingga menjadi budaya. (7) Meningkatkan kemmapuan menggunakan bahasa internasional. (8) Mengembangkan teknologi informasi dan komunikasi dalam pembelajaran dan administrasi. Adapun yang ketiga, tujuan "Terarahnya pelaksanaan program pendidikan yang terintegrasi kepada Visi dan Misi SD Muhammadiyah 7 dengan Visi Misi Pendidikan Nasional, dengan prioritas program setahun kedepan, menekankan pada gemar beribadah, gemar menuntut ilmu dan mampu bersaing secara global, cinta kebersihan dan menjalankan aturan sesuai syariat Islam."

Dari visi, misi dan tujuan SD Muhammadiyah 7 Pekanbaru tersebut dapat dipahami bahwa sekolah ini menekankan pada gemar beribadah, gemar menuntut ilmu dan mampu bersaing secara global, cinta kebersihan dan menjalankan aturan sesuai syariat Islam. hal tersebut sesuai dengan isi atau materi pendidikan yang berhubungan dengan (iman, islam, ihsan, islah dan amal shaleh) yang menjadi ciri has dari sekolah ini membedakan sekolah ini dengan sekolah umum.

Namun tidak lengkap pengakuan tersebut kalau tidak melaui sebuah kajian atau penelitian dilapangan. Hal ini yang menjadi daya tarik bagi penulis untuk melakukan kunjungan dan sekaligus melakukan observasi dan wawancara dengan beberapa orang yang menjadi representatif dari sekolah dasar muhammadiyah 7 pekanbaru. dari hasil wawancara penulis dengan kepala sekolah tentang implementasi materi atau isi pendidikan yang mencakup bidang iman, islam, ihsan, amal shaleh dan islah mengungkapkan bahwa sesuai denga visi sekolah SD Muhammadiyah 7 Pekanbaru yaitu Terwujudnya Lembaga Pendidikan Islami yang berprestasi, berbudaya ilmu pengetahuan, teknologi, seni budaya dan lingkungan, serta mampu berdaya saing secara global.

Hal ini juga dibuktikan dengan pengamatan penulis bahwa program pembelajaran yang diterapkan mengacu pada materi iman, islam, ihsan, amal saleh dan islah sehingga mulai dari gurunya hingga siswa menujukan sikap yang baik dalam dalam bertutur dan bertindak sesuai dengan materi iman, islam, dan ihsan.

Selanjutnya kegiatan-kegiatan seperti solat berjama'ah membiasakan solat duha ketika pagi itu sudah menjadi hal biasa dijalankan oleh warga sekolah sd muhammadiyah 7 pekanbaru. Dari hasil wawancara dan pengamatan penulis tersebut dapat disimpulkan bahwa penerapan materi tentang iman, islam, ihsan, amal saleh, dan islah itu sudah dilakukan Di Sekolah Dasar Muhammadiyah 7 Pekanbaru.

\section{PENUTUP}

\section{A. Kesimpulan}

Sekolah dasar muhammadiyah 7 pekanbaru pada prinsipnya sudah melaksanakan dan mengimplementasikan isi atau materi pendidikan tentang iman, islam, ihsan, amal shaleh dan islah dalam program dan pembelajaran. hal ini sesuai dengan tujuan sekolah ini yaitu: Terarahnya pelaksanaan program pendidikan yang 
terintegrasi kepada Visi dan Misi SD Muhammadiyah 7 dengan Visi Misi Pendidikan Nasional, dengan prioritas program setahun kedepan, menekankan pada gemar beribadah, gemar menuntut ilmu dan mampu bersaing secara global, cinta kebersihan dan menjalankan aturan sesuai syariat Islam.

\section{B. Saran}

Dari hasil pengamatan dan wawancara penulis maka dapat direkomendarikan kepada pihak sekolah lebih meningkatkan lagi proses pemahaman bagi guru-guru nya mengenai materi iman, islam, ihsan, amal saleh dan islah sehingga hal ini mempermudah guru dalam menerapkannya dalam proses belajar mengajar dilingkunngan sekolah tersebut. hal yang mendasar yang perlu dilakukan oleh seorang guru menurut penulis adalah mengenai materi iman, islam, ihsan, amal saleh dan islah karena ini merupakan materi yang mendasar dan sangat pokok untuk diajarkan dalam jenjang pendidikan yang dasar yaitu sekolah dasar muhammadiyah 7 pekanbaru.

Selanjutnya penulis juga meminta masukan bagi perbaikan tulisan ini kedepan sehingga menjadi karya ilmiah yang bermanfaat untuk bahan bacaan bagi pihak sekolah.

\section{DAFTAR PUSTAKA}

Abdul Rahman Abdul Khalid, Garis Pemisah antara Kufur dan Iman, (Jakarta, Bumi Aksara,1996)

Abi al-Husain Ahmad ibn Fãris ibn Zakaria,

Lughah, (Mesir: Maktabah alKhabakhiy, 1981)

Abd Salam, (Teheran: Maktabat al-Ilmiyah, t.th)
Abu 'Ali al-Fadl ibn al-Hasan atThabarsi,

Ma'rifah, 1986)

Al-Raghib al-Asfahani, Mufradat alfaz al-Quran (Beirut:

Dar al-Kutub al-Ilmiyah, 2004)

Ahmad Syafi'i Ma'arif, $A l$ Realitas Sosial dan Limbo Sejarah (Sebuah refleksi), (Bandung: Penerbit Pustaka, 1985)

Abu Muhammad Mahmud Ibn Ahmad al-Aynayni, al-Bidãyah fi Syarh alhidãyah, (Beirut: Dar al-Fikr, t,th)

Ahmad Ibnu Faris bin Zakariyya, $-1972 \mathrm{H}$, -lugah, $1392 \mathrm{H}$

Dimiyati, Belajar dan Pembelajaran, (Jakarta: Rineka Cipta, 2002)

Djaka, Kamus Lengkap Bahasa Indonesia Masa Kini,( Surakarta : Pustaka Mandiri, 2011), Siswanto, Pengantar Manajemen, (Jakarta: Bumi Aksara, 2006),

Evelin Siregar \& Hartini Nara, Teori Belajar dan Pembelajaran (Bogor: Ghalia Indonesia, 2010)

E. van Donzel, B. Lewis, dkk (ed), Encyclopedia of Islam, (Leiden: E.J. Brill, 1990)

HAR. Gibb and JH Krammers, Shorter Encyclopaedia of islam, (E.J. Brill, Leiden, 1974)

Hasan Langgulung,. Pendidikan Islam Menghadapi Abad ke-21, Jakarta : Pustaka al-Husna. 1996

Hassan Sadyli dkk, Ensikolopedi Indonesia, (Jakarta: Ichtiar baru Van Hoeve, 1982)

Hammudah Abdalati, Islam Suatu Kepastian, (Media Da'wah, 1983) 
Isjon, Pembelajaran Cooperatif, Meningkatkan Kecerdasan Komunikasi antara peserta didik, (Yogyakarta: Pustakan Pelajar, 2009)

John O. Voll, Renewal and Reform in Islamic History: Tajdid and Ishlãh dalam John L. Esposito, Voices of Resurgent, (New York: Oxford University Press, 1983)

Jj. Hasibuan, Proses Belajar mengajar, (Bandung: Remaja Rosda Karya, 1986)

Muhammad Ali, Guru dalam Proses Belajar Mengajar,(Bandung: Sinar Baru, 2008)

Kaelany HD, Iman, Ilmu dan Amal Saleh, (Jakarta: Rineka Cipta, 2000)

Muhammad Nur Abdul Hafizh Suwaid, Mendidik Anak Bersama Rasulullah (terj. Kuswandani dari Manhaj al Tarbiyah al Nabawiyah li al Thifl), (Al Bayan, Bandung, 2000)

Mahsun Fuad, Hukum Islam Indonesia; Dari Nalar Partisipatoris Hingga Emansipatoris (Yogyakarta: LKis, 2005)

M. Yatimin Abdullah, Studi Islam Kontemporer, (Jakarta: Amza, 2006)

Muhammad Fuad Abd al-Bâqî, al-Mufahras li Alfâzh al(Darul Fikr, 1981)

Mihmidaty Ya'cub, Pendidikan Tassawuf dan Aplikasinya (Surabaya: IAIN Sunan Ampel Press, 2013)

Made Wena, Strategi Pembelajaran Inovatif Kontemporer. (Jakarta: Bumi Aksara. 2009)
Muhammad Fuad Abdul Baqi, alal-Mufharras li Alfaz alQuran al-Karim, Beirut, Dar Fikr 1981)

Qamaruddin Saleh, H.A.A Dahlan dkk. Asbab al-Nuzul(Latar Belakang Historis Turunnya Ayat-ayat Al- ), (Bandung: Penerbit CV. Diponegoro, 1985)

Qurais Syihab, "Iman dan Amal Saleh",( Amanah, no 87, November 1988)

Rif'at Syauqi, Rasionalitas Tafsir Muhammad Abduh; Kajian Masalah Akidah dan Ibadat (Jakarta: Paramadina, 2002)

Sri Esti Wuryani, Psikologi Pendidikan, (Jakarta: Raja Grafindo Persada, 2002)

Syaiful Sagala, Konsep dan Makna Pembelajaran (Bandung: Alfabeta, 2010)

Sayid Sabiq, Fiqh al- Sunnah, terj., Kamaludin A. Marzuki dengan judul Fiqih Sunnah, (Bangdung: PT. Al-Ma'arif, 1988)

Slameto, Belajar dan Faktor-Faktor Mempengaruhinya, (Jakarta: Rineka Cipta, 1995)

Walker. "What Curriculum Research?" dalam Curriculum And Instruction. Henry A. Giroux, et al. McCutchan USA : Publishing Corporation. 1981

Walter W. Mc Mahon, Sistem manajemen Berbasis Efesiensi, (Jakarta: Logos, 2004)

WJS. Poerwadarminta, Kamus Umum Bahasa Indonesia, (Jakarta: Balai Pustaka, 2000)

Zuhairini, Filsafat Pendidikan Islam, (Jakarta: Rajawali Press, 1995). 